\title{
Land Suitability Evaluation for Oil Palm (Elaeis guineensis Jacq.) in Coastal Plains of Southwest Cameroon
}

\author{
Georges Kogge Kome*, Fritz Oben Tabi, Roger Kogge Enang, Francis Brice Tedou Silatsa \\ Department of Soil Science, Faculty of Agronomy and Agricultural Sciences (FASA), University of Dschang, Dschang, \\ Republic of Cameroon \\ Email: *komegeo@yahoo.fr
}

How to cite this paper: Kome, G.K., Tabi, F.O., Enang, R.K. and Silatsa, F.B.T. (2020) Land Suitability Evaluation for Oil Palm (Elaeis guineensis Jacq.) in Coastal Plains of Southwest Cameroon. Open Journal of Soil Science, 10, 257-273.

https://doi.org/10.4236/ojss.2020.107014

Received: June 2, 2020

Accepted: June 27, 2020

Published: July 1, 2020

Copyright $\odot 2020$ by author(s) and Scientific Research Publishing Inc. This work is licensed under the Creative Commons Attribution International License (CC BY 4.0).

http://creativecommons.org/licenses/by/4.0/

\begin{abstract}
Declining yields in oil palm fresh fruit bunch (FFB) have been recorded over the past years in the coastal lowlands of southwest Cameroon and current actual yields are very low $\left(<12 \mathrm{t} \mathrm{FFB} \mathrm{ha}{ }^{-1} \cdot \mathrm{yr}^{-1}\right)$ compared to the potential yields $\left(25 \mathrm{t} \mathrm{FFB} \mathrm{ha} \mathrm{h}^{-1} \cdot \mathrm{yr}^{-1}\right)$. One of the problems limiting optimum oil palm production is lack of detailed pedological information to guide plantation establishment and management. A land suitability evaluation was carried out for some major oil palm producing areas of southwest Cameroon to identify land qualities limiting optimal production. Thirteen sites ( 9 with sedimentary parent materials and 4 with volcanic parent material) were evaluated using a parametric method. Results indicate that climate was not a major limiting factor for oil palm production in coastal plains of southwest Cameroon. However, soil physical characteristics (mainly clayey texture and poor drainage) and soil fertility constitute limitations to oil palm production. Specifically, limitations in cation exchange capacity (CEC), base saturation (BS), organic carbon (OC) and $\mathrm{pH}$ were slight to moderate while $\mathrm{K}$ mole fraction was the most severe and the most limiting in all the sites. The fertility limitations were more pronounced in soils derived from sedimentary parent materials where $33 \%$ had limitations caused by soil $\mathrm{pH}$ and OC compared to none for volcanic soils. In addition, $77.8 \%$ of sedimentary soils had limitations caused by CEC compared to $25 \%$ for volcanic soils. Considering the overall suitability, soils derived from volcanic parent materials were potentially more suitable for oil palm cultivation ((S3)-50\%, (S2)-50\%) compared to sedimentary soils $((\mathrm{N})-11 \%$, (S3) $-78 \%$ and $(\mathrm{S} 2)-11 \%)$. Based on the suitability classes of the different soils derived from dissimilar parent materials, appropriate site-specific soil management is needed to improve oil palm yields, especially with emphasis on $\mathrm{K}$ fertilization and improved soil water management. Plan-
\end{abstract}


tation management in coastal plains of South West Cameroon therefore should factor in differences in soil parent material.

\section{Keywords}

Land Evaluation, Oil Palm, K Mole Fraction, Soil Parent Material, Coastal Plain Soils

\section{Introduction}

The oil palm (Elaeis guineensis Jacq.) is the most productive oil crop in terms of oil yield per hectare and resource use efficiency due to its high ability at transforming solar energy into vegetable oil. The optimal yield of palm oil is about 4.2 $\mathrm{t} \cdot \mathrm{ha}^{-1} \cdot \mathrm{year}^{-1}$, and can exceed $6.0 \mathrm{t} \cdot \mathrm{ha}^{-1} \cdot \mathrm{yr}^{-1}$ in the best-managed plantations [1]. The oil palm is an international commodity used for food, household and industrial purposes, and its demand is very high [2]. Soil fertility management in oil palm plantations has been identified as a key to successful and sustainable oil palm production [3]. With respect to oil palm cultivation, land suitability assessment studies have been carried out both intensively and extensively in Southeast Asia and parts of South America, and it is reported that more than $95 \%$ of oil palms are grown on highly weathered and acidic tropical soils having a low fertility status [4]. In Nigeria, relationships between oil palm yields and soil nutrients have been established, and it has been concluded that soil fertility is a major constraint to sustainable oil palm production [3]. In Cameroon, about $66 \%$ of the total surface area is suitable for oil palm cultivation-i.e. about $31,233,650$ ha, of which $1,366,920$ ha are highly suitable with an estimated current cultivated area of only 123,000 ha (about $9 \%$ of highly suitable area) [5]. If oil palm production has to be sustained, detailed soil fertility investigations coupled to land suitability assessment need to be carried out.

In Cameroon, oil palm is a major income generating crop to most companies and small holder farmers. Although the area under oil palm cultivation has significantly increased over the past decades, corresponding yields per unit area have been declining, and current actual yields are very low $\left(<12 \mathrm{t} \mathrm{FFB} \mathrm{ha}^{-1} \cdot \mathrm{yr}^{-1}\right)$ compared to the potential yields $\left(25 \mathrm{t} \mathrm{FFB} \mathrm{ha} \mathrm{h}^{-1} \cdot \mathrm{yr}^{-1}\right)$. This has made Cameroon remain a net importer of palm oil due to the high national demand especially for industrial transformation (mostly for soap production). From 1999-2004, the import of vegetable oils in Cameroon increased by $366.3 \%$ with palm oil accounting for $55 \%$ of the imports [6]. Thus, there is an urgent need to increase oil palm yields in Cameroon in order to satisfy the increasing demand. A prerequisite for sustainable intensification of oil palm production is to have reliable information about the soil's suitability so as to adopt appropriate management strategies. In the coastal lowlands of southwest Cameroon, generalized studies on land suitability evaluation for oil palm have been carried out. For example, the soils and landscapes of the lower eastern slopes of mount Cameroon (i.e. the 
Tiko plain, the Mungo area and the Mpundu-Meanja area) were evaluated for various perennial crops including the oil palm [7]. In this evaluation, emphasis was laid on the boundaries between different landscapes and soil types, notably volcanic and non-volcanic soils [7] - however, it has been reported that the seemingly uniform soil patterns observed in the Tiko plain show great variability in soil types and properties [8]. Another land suitability evaluation was conducted for oil palm cultivation in the Boa plain (West and Northwest of Mount Cameroon) and it was reported that the soils were in general fertile and suitable for the cultivation of oil palm but it was also noticed that some areas within the plain were susceptible to flooding and thus necessitated some specific management considerations [9]. Recently, an oil palm suitability map for southwest Cameroon was established, taking into account climatic data, soil types and topography [10] [11]. Although such works have been performed, actual yields in the coastal lowlands of Cameroon remain far below their potential. Also, the yields appear to vary in space, indicating that soil characteristics and soil nutrients in different locations might influence the yields, owing to their spatial variability even at the local scale. Following the observed decline in yields, most oil palm producers believe that an increase in oil palm production is synonymous to the opening of new farmlands despite the numerous environmental consequences associated with it. The objective of this study was therefore to compare the actual and potential productivity of some major soil types with respect to oil palm yield, derived from different parent materials, through the use of a parametric method of land suitability evaluation. This information will guide plantation management in relation to intensification.

\section{Materials and Methods}

\subsection{Location of Study Area, Soil Sampling and Laboratory Analysis}

The study was carried out in the coastal lowlands of southwest Cameroon, a region where large oil palm estates and many small holder plantations are located. Thirteen sites (nine with sedimentary parent materials and four with volcanic parent materials) distributed throughout the area were selected to represent the distinct ecological and physiographic zones. The geographical locations and some important site characteristics are represented in Figure 1 and Table 1. At each site, a representative soil profile was characterized and sampled. Samples from the field were air-dried at room temperature, crushed and sieved through a $2 \mathrm{~mm}$ sieve. The $<2 \mathrm{~mm}$ soil fraction was analyzed for physical and chemical properties. Particle size analysis was done using the hydrometer method after dispersion of $50 \mathrm{~g}$ of soil with $2.5 \mathrm{~N}$ sodium hexametaphosphate solution [12]. Soil organic carbon content was determined by the Walkley-Black wet combustion method by oxidation with potassium dichromate and titration with iron (II) sulphate. Soil $\mathrm{pH}$ was measured in a 1:2.5 soil: solution ratio in $1 \mathrm{~N} \mathrm{KCl}$ $(\mathrm{pH}-\mathrm{KCl})$ and distilled water $\left(\mathrm{pH}-\mathrm{H}_{2} \mathrm{O}\right)$. Total $\mathrm{N}$ and available phosphorous 


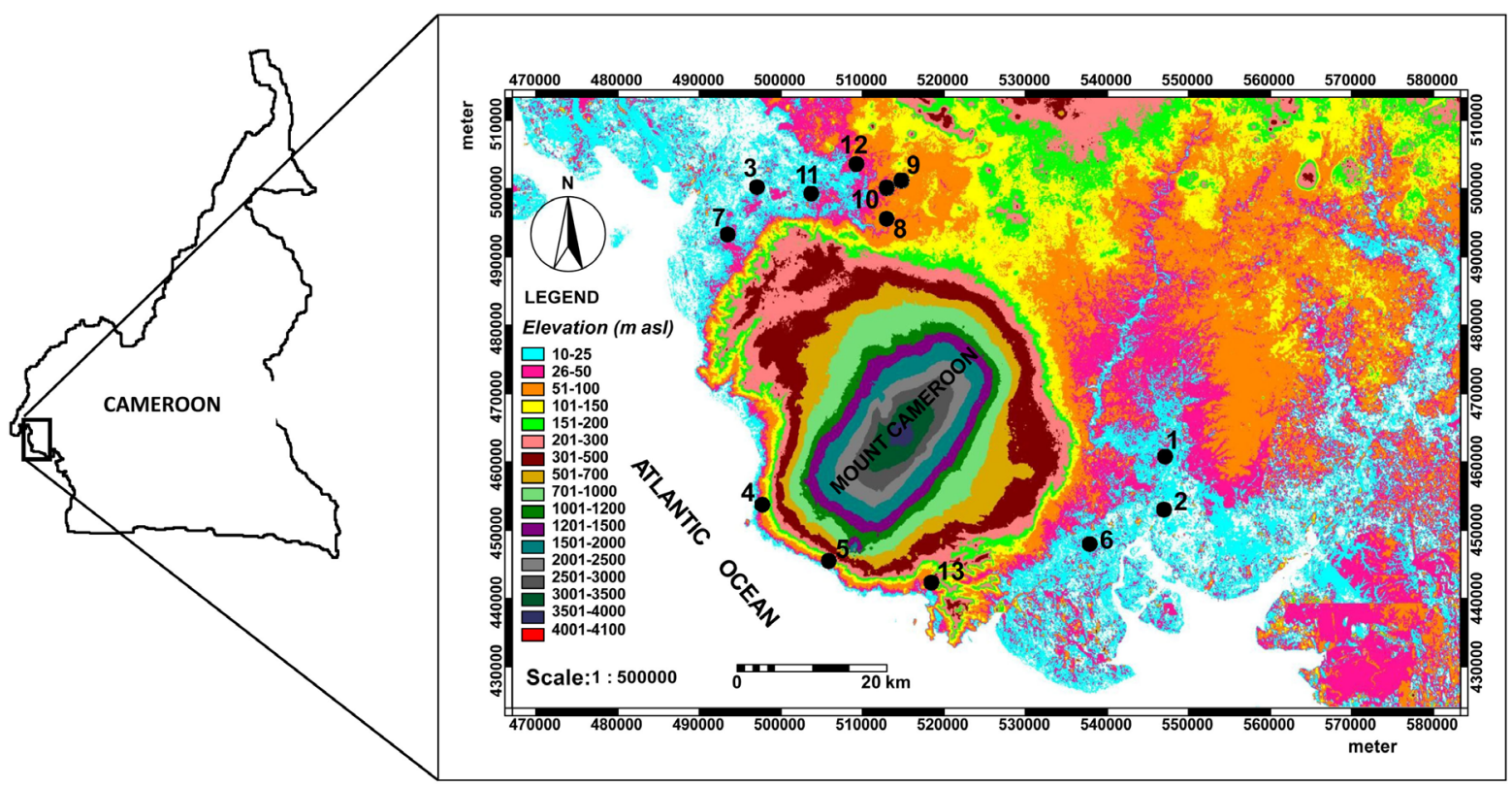

Figure 1. Topographic map showing location of the study sites in southwest Cameroon. 1-Mondoni, 2-Essoasso, 3-Illoani, 4-Debundscha, 5-Bakingili, 6-Likomba, 7-Boa, 8-Dieka, 9-Mafanja, 10-Kumbe, 11-Meme, 12-Mbonge, 13-Bota.

Table 1. Description of sites and classification of representative soil profiles used for land suitability evaluation.

\begin{tabular}{|c|c|c|c|c|c|c|c|c|c|}
\hline Site & $\begin{array}{c}\text { Latitude } \\
\left({ }^{\circ}\right)\end{array}$ & $\begin{array}{l}\text { Longitude } \\
\quad\left({ }^{\circ}\right)\end{array}$ & Topography & $\begin{array}{c}\text { Elevation } \\
(\mathrm{m} \cdot \mathrm{asl})\end{array}$ & SMR & STR & Drainage & Parent material & $\begin{array}{l}\text { Soil classification } \\
\text { (US Taxonomy, }\end{array}$ \\
\hline Mondoni & 4.168672 & 9.424169 & Flat & 34 & Udic & Isohyperthermic & Poor & $\begin{array}{c}\text { Young } \\
\text { alluvial sediments }\end{array}$ & $\begin{array}{c}\text { Fluvaquentic } \\
\text { Eutropepts }\end{array}$ \\
\hline Essoasso & 4.098484 & 9.422990 & Flat & 8 & Udic & Isohyperthermic & $\begin{array}{c}\text { Moderately } \\
\text { well drained }\end{array}$ & $\begin{array}{l}\text { Young alluvial and } \\
\text { fluvio-marine } \\
\text { sediments }\end{array}$ & $\begin{array}{c}\text { Aquic } \\
\text { Tropohumults }\end{array}$ \\
\hline Illoani & 4.515680 & 9.012316 & Flat & 18 & Perudic & Isohyperthermic & Poor & $\begin{array}{l}\text { Recent } \\
\text { alluvial sediments }\end{array}$ & Udifluvents \\
\hline Debundscha & 4.101442 & 9.006395 & $\begin{array}{l}\text { Slightly } \\
\text { sloping }\end{array}$ & 98 & Udic & Isohyperthermic & Good & $\begin{array}{c}\text { Pyroclastic } \\
\text { materials }\end{array}$ & $\begin{array}{c}\text { Typic } \\
\text { Hydrandepts }\end{array}$ \\
\hline Bakingili & 4.06544 & 9.03595 & Sloping & 120 & Udic & Isohyperthermic & Good & $\begin{array}{l}\text { Pyroclastic } \\
\text { materials } \\
\text { with basalt }\end{array}$ & $\begin{array}{c}\text { Hydric } \\
\text { Dystrandept }\end{array}$ \\
\hline Likomba & 4.052832 & 9.340972 & Flat & 28 & Udic & Isohyperthermic & $\begin{array}{l}\text { Moderately } \\
\text { well drained }\end{array}$ & Alluvial deposits & $\begin{array}{c}\text { Typic } \\
\text { Tropudalfs }\end{array}$ \\
\hline Boa & 4.462386 & 8.941039 & Flat & 26 & Perudic & Isohyperthermic & Poor & Alluvium & Tropudults \\
\hline Dieka & 4.50514 & 9.13353 & Flat & 40 & Udic & Isohyperthermic & $\begin{array}{l}\text { Poor to } \\
\text { moderate }\end{array}$ & $\begin{array}{c}\text { Young } \\
\text { alluvial deposits }\end{array}$ & Udifluvents \\
\hline Mafanja & 4.533333 & 9.116667 & Flat & 60 & Udic & Isohyperthermic & Good & Sandy materials & Udipsamments \\
\hline Kumbe & 4.555086 & 9.066694 & Flat & 31 & Udic & Isohyperthermic & Moderate & $\begin{array}{c}\text { Young } \\
\text { alluvial deposits }\end{array}$ & $\begin{array}{c}\text { Typic } \\
\text { Tropudalfs }\end{array}$ \\
\hline Meme & 4.533695 & 9.130413 & Flat & 30 & Udic & Isohyperthermic & Moderate & $\begin{array}{l}\text { Old } \\
\text { sedimentary } \\
\text { materials }\end{array}$ & Udipsamments \\
\hline Mbonge & 4.519883 & 9.113012 & Flat & 20 & Udic & Isohyperthermic & Good & Basalt & Hapludalfs \\
\hline
\end{tabular}

Notes: SMR, soil moisture regime; STR, soil temperature regime. 
were determined by the Kjeldahl wet digestion and the Bray II methods, respectively. Exchangeable bases $\left(\mathrm{Na}^{+}, \mathrm{K}^{+}, \mathrm{Ca}^{2+}, \mathrm{Mg}^{2+}\right)$ were determined following the Schollenberger method by leaching $2.5 \mathrm{~g}$ of soil with $100 \mathrm{~mL}$ of a $1 \mathrm{M}$ ammonium acetate solution buffered at $\mathrm{pH}$ 7. The concentrations of $\mathrm{Na}^{+}$and $\mathrm{K}^{+}$ions in the extract were obtained by flame photometry, and those of $\mathrm{Ca}^{2+}$ and $\mathrm{Mg}^{2+}$ were estimated by complexometric titration using a $0.002 \mathrm{M} \mathrm{Na}_{2}$-EDTA solution. Cation exchange capacity (CEC) was estimated by leaching $2.5 \mathrm{~g}$ of soil with $100 \mathrm{~mL}$ of a $1 \mathrm{M}$ ammonium acetate solution buffered at $\mathrm{pH} 7$ and then with $1 \mathrm{~N} \mathrm{KCl}$, and the displaced $\mathrm{NH}_{4}^{+}$ions determined by distillation and titration with $0.01 \mathrm{~N}$ sulphuric acid. Base saturation percent was estimated from exchangeable bases and CEC using the summation method [13].

\subsection{Procedure for Land Suitability Evaluation}

In carrying out the land evaluation process, the soil profiles (up to $100 \mathrm{~cm}$ depth) were first placed in suitability classes by matching their characteristics/properties (Table 2 and Table 3 ) with the requirements for oil palm (Table 4) [14] [15] [16] [17] [18]. The suitability class of a pedon (aggregate suitability) is that indicated by its most limiting characteristics, this according to Liebig's Law of the minimum which states that crop growth and yield is regulated by the factor in greatest limitation, and yields can be increased only by correction of that limiting factor. Next, a parametric method was used to rate each limiting characteristic as in Table 5.

From the various ratings, the index of productivity (IP) for each pedon was calculated using the equation:

Table 2. Climatic variables in the different study sites.

\begin{tabular}{ccccccc}
\hline Site & $\mathrm{P}(\mathrm{mm})$ & $\mathrm{LDS}(\mathrm{months})$ & $\mathrm{Tmax}\left({ }^{\circ} \mathrm{C}\right)$ & $\mathrm{Tmin}\left({ }^{\circ} \mathrm{C}\right)$ & $\mathrm{Tav}\left({ }^{\circ} \mathrm{C}\right)$ & $\mathrm{RH}(\%)$ \\
\hline Mondoni & 3081 & 3 & 26.9 & 24.5 & 26.0 & $>80$ \\
Essoasso & 2975 & 3 & 26.6 & 24.2 & 25.6 & $>80$ \\
Illoani & 3470 & 3 & 26.9 & 24.9 & 25.6 & $>80$ \\
Debundscha & 9099 & 2 & 26.7 & 24.6 & 25.6 & $>80$ \\
Bakingili & 3817 & 2 & 26.1 & 24.0 & 25.2 & $>80$ \\
Likomba & 2975 & 3 & 26.6 & 24.2 & 25.6 & $>80$ \\
Boa & 3470 & 3 & 26.9 & 24.9 & 25.6 & $>80$ \\
Dieka & 3180 & 3 & 29.3 & 22.8 & 26.0 & $>80$ \\
Mafanja & 3000 & 3 & 29.3 & 22.8 & 26.0 & $>80$ \\
Kumbe & 3227 & 3 & 27.1 & 24.9 & 26.2 & $>75$ \\
Meme & 2751 & 3 & 26.5 & 23.9 & 25.5 & $>75$ \\
Mbonge & 2161 & 3 & 25.1 & 22.6 & 24.1 & $>75$ \\
Bota & 3517 & 3 & 30.2 & 21.6 & 25.3 & $>80$ \\
\hline
\end{tabular}

Notes: $\mathrm{P}=$ Annual rainfall; LDS = Length of dry season; Tmax = Mean annual maximum temperature; Tmin = Mean annual minimum temperature; Tav = Mean annual temperature; $\mathrm{RH}=$ Relative humidity. 
Table 3. Land qualities/characteristics in the different soil series used for land suitability evaluation.

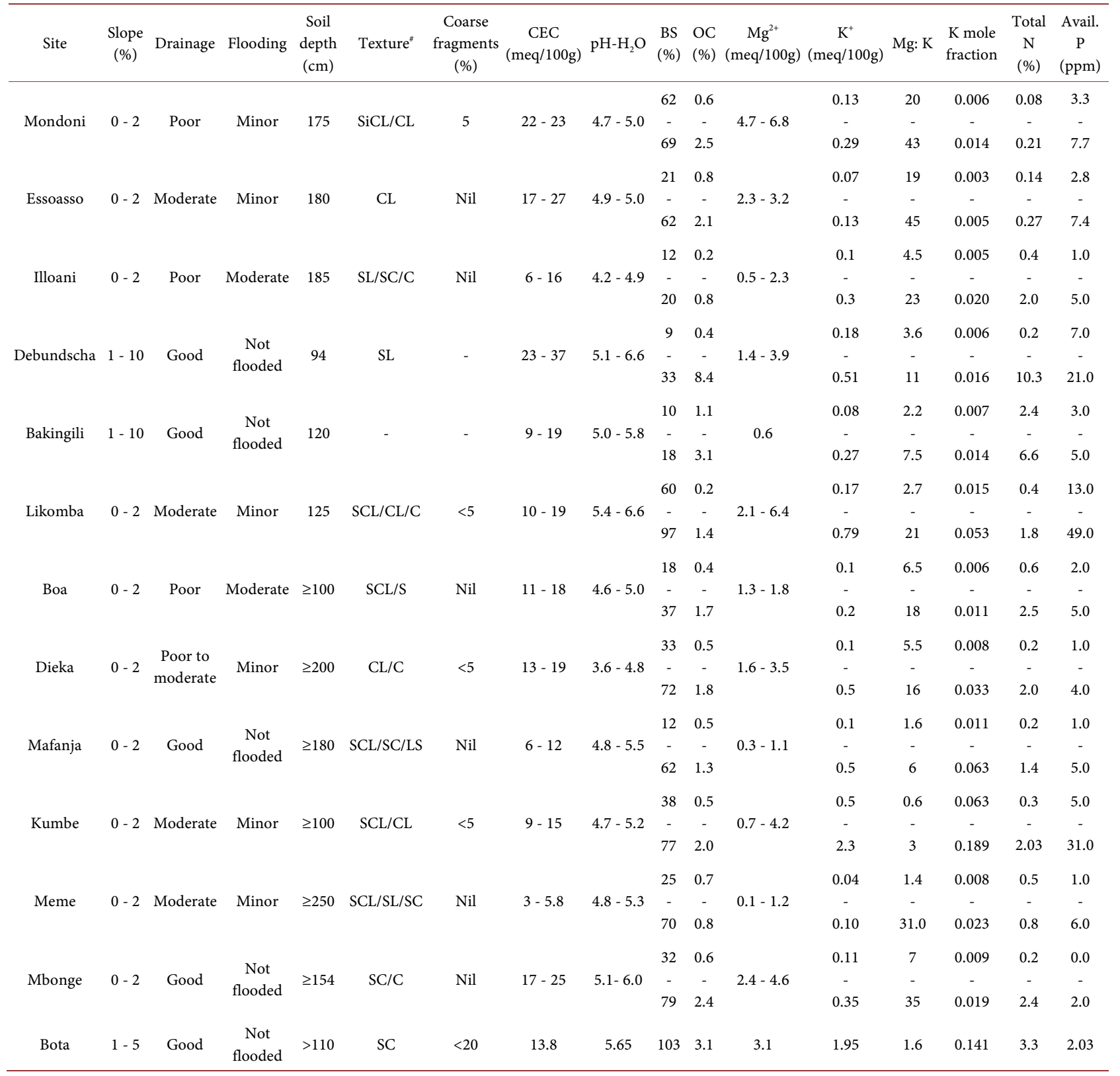

"SiCL, silty clay loam; CL, clay loam; SL, sandy loam; SCL; sandy clay loam; SC, sandy clay; C, clay.

Table 4. Land requirements for the production of oil palm.

\begin{tabular}{cccccc}
\hline & \multicolumn{5}{c}{ Land suitability classes } \\
\cline { 2 - 6 } Land Requirements/ \\
\cline { 2 - 6 } Characteristics & $\mathrm{S} 1$ & $\mathrm{~S} 2$ & $\mathrm{~S} 3$ & $\mathrm{~N} 1$ & $\mathrm{~N} 2$ \\
& $(85 \%-100 \%)$ & $(60 \%-85 \%)$ & $(40 \%-60 \%)$ & $(25 \%-40 \%)$ & $(0 \%-25 \%)$ \\
\hline Climate (c) & & & & & \\
Annual rainfall (mm) & $>2000$ & $1700-2000$ & $1450-1700$ & $1250-1450$ & $<1250$ \\
Length of dry season (months) & $<1$ & $1-2$ & $2-3$ & $3-4$ & $>4$ \\
Mean annual max. temp. $\left({ }^{\circ} \mathrm{C}\right)$ & $>29$ & $27-29$ & $24-27$ & $22-24$ & $<22$ \\
Mean annual min. temp. $\left({ }^{\circ} \mathrm{C}\right)$ & $>20$ & $18-20$ & $16-18$ & $14-16$ & $<14$ \\
\hline
\end{tabular}




\section{Continued}

\begin{tabular}{|c|c|c|c|c|c|}
\hline Mean annual temp. $\left({ }^{\circ} \mathrm{C}\right)$ & $>25$ & $22-25$ & $20-22$ & $18-20$ & $<18$ \\
\hline Relative humidity (\%) & $>75$ & $70-75$ & $60-70$ & - & $<60$ \\
\hline \multicolumn{6}{|l|}{ Topography (t) } \\
\hline Slope (\%) & $0-8$ & $8-16$ & $16-30$ & $30-50$ & $>50$ \\
\hline \multicolumn{6}{|l|}{ Wetness (w) } \\
\hline Drainage class & $\begin{array}{l}\text { Moderate to } \\
\text { Imperfect }\end{array}$ & $\begin{array}{c}\text { Well and } \\
\text { somewhat } \\
\text { excessive }\end{array}$ & $\begin{array}{c}\text { Poor (aeric) } \\
\text { (easily } \\
\text { drained) }\end{array}$ & $\begin{array}{c}\text { Poor (typic) } \\
\text { (difficult } \\
\text { to drain) }\end{array}$ & Very poor \\
\hline Flooding & Not flooded & Not flooded & Minor & Moderate & Severe \\
\hline \multicolumn{6}{|l|}{ Soil physical properties (s) } \\
\hline Texture/structure & CL, SCL, L & SCL & SCL - LFS & Any & $\mathrm{C}, \mathrm{CS}$ \\
\hline $\begin{array}{l}\text { Coarse fragments }(\mathrm{Vol} \%) \\
0-10 \mathrm{~cm}\end{array}$ & $<5$ & $5-15$ & $15-35$ & $35-45$ & $>45$ \\
\hline Depth $(\mathrm{cm})$ & $>100$ & $75-100$ & $50-75$ & $25-50$ & $<25$ \\
\hline \multicolumn{6}{|l|}{ Soil fertility conditions (f) } \\
\hline $\mathrm{CEC}(\mathrm{meq} / 100 \mathrm{~g})$ & $\geq 16$ & $<16$ & - & - & - \\
\hline $\mathrm{pH}$ topsoil & $5.0-5.8$ & $\begin{array}{l}4.5-5.0 \\
6.0-7.0\end{array}$ & $4.0-4.5$ & $<4.0,>7.0$ & $<4.0,>7.0$ \\
\hline Base saturation (\%) & $>35$ & $20-35$ & $<20$ & - & - \\
\hline Organic carbon (\%) $0-15 \mathrm{~cm}$ & $\geq 1.5$ & $<1.5$ & - & - & - \\
\hline Mg: K ratio & $>3.5$ & $2-3.5$ & $1-2$ & - & - \\
\hline $\mathrm{K}$ (mole fraction) & $>1.75$ & $1.5-1.75$ & $1.2-1.5$ & $<1.2$ & $<1.2$ \\
\hline \multicolumn{6}{|l|}{ Salinity and alkalinity (n) } \\
\hline $\mathrm{EC}(\mathrm{dS} / \mathrm{m})(50 \mathrm{~cm})$ & $<1.0$ & $1.0-2.0$ & $2.0-3.0$ & $3.0-4.0$ & $>4.0$ \\
\hline
\end{tabular}

Notes: CL, clay loam; SCL, sandy clay loam; L, loam; LFS, loamy fine sand; C, clayey; CS, clayey sand; CEC = cation exchange capacity; EC = electrical conductivity. Source: Adapted from [14] [15] [16] [17] [18].

Table 5. Rating of limiting characteristics.

\begin{tabular}{cc}
\hline Limitation & Land Index \\
\hline None & $70-100$ \\
Slight & $55-69$ \\
Moderate & $40-54$ \\
Severe & $20-39$ \\
Very severe & $0-19$ \\
\hline
\end{tabular}

$$
\mathrm{IP}=A \times \sqrt{\frac{B}{100} \times \frac{C}{100} \times \frac{D}{100}} \times \cdots
$$

where $A$ is the overall lowest characteristic rating, and $B, C, D$, etc., are the lowest characteristics ratings for each land quality group. The groups of land qualities or characteristics used are climate (c), topography (t), soil physical proper- 
ties (s), wetness ( $w)$ and chemical fertility (f). Two productivity indices were calculated using Equation (1). First, the potential index of productivity (IPp) was determined by excluding $\mathrm{K}$ mole fraction and $\mathrm{Mg}$ : $\mathrm{K}$ ratio from the chemical fertility (f) group. Secondly, the actual or current index of productivity (IPc) was determined by including $\mathrm{K}$ mole fraction and Mg: $\mathrm{K}$ ratio in the chemical fertility ( $\mathrm{f}$ ) group. The $\mathrm{K}$ mole fraction in this case was calculated as the ratio of exchangeable $\mathrm{K}$ divided by cation exchange capacity. The $\mathrm{K}$ mole fraction, also known as the $\mathrm{K}$ saturation index, is an important index for assessing soil $\mathrm{K}$ status [19]. In computing the IP values, only one member in each group was used due to the correlation that exists among members of the same group [17]. Overall suitability classes S1 (Highly suitable), S2 (Moderately suitable), S3 (Marginally suitable) and $\mathrm{N}$ (Not suitable) for each pedon are equivalent to IP values of $100-75,74-50,49-25$ and $24-0$, respectively.

\section{Results and Discussion}

\subsection{Soil Reaction and Base Saturation}

The results indicate that all the soils had $\mathrm{pH}$ values that ranged from high to very high $(\mathrm{pH}>4.2)$ except for Dieka where some horizons had low $\mathrm{pH}$ values $(\mathrm{pH}<$ $4.0)$. The $\mathrm{pH}$ values observed in these areas indicate that soil acidity is not a major constraint to oil palm growth. Although the $\mathrm{pH}$ values are generally high in almost all sites, there are differences in $\mathrm{pH}$ values ranging from 0.1 to 3.0 units across the different sites. These differences in $\mathrm{pH}$ values can lead to significant differences in soil acidity across the different sites, which in turn influence the availability and quantity of nutrient elements. Soil $\mathrm{pH}$ is a parameter which is highly variable, even within a plantation, this as a result of the large spatial variability in soil organic matter, microbial activity, fertilizer application and water uptake [20]. Correlation analysis (Table 6) indicates that there is a significant ( $\mathrm{p}$ $<0.01$ ) and positive correlation between soil $\mathrm{pH}$ and $\mathrm{Ca}^{2+}, \mathrm{Mg}^{2+}$ and $\mathrm{Na}^{+}$and base saturation. These basic cations are usually needed in sufficient quantities so as to prevent or correct soil acidification. The relationship between basic cations and soil $\mathrm{pH}$ indicate that soil $\mathrm{pH}$ is an important soil parameter to be considered in the management of these soils, given that changes in soil $\mathrm{pH}$ either in space or time may significantly affect plant nutrient availability and yield. It has been reported that soil acidification in Indonesia and Papua New Guinea as influenced by chemical fertilizers or inherently acidic parent materials can have significant negative effects on oil palm yields, but if well managed, acidic soils can produce relatively high oil palm yields [20]. Base saturation percent varied across the different soils and was generally higher $(>35 \%)$ in soils of Mondoni, Likomba, Kumbe and Bota. On the other hand, low values of BS were observed in soils of Illoani, Debundscha and Bakingili. The low BS values contribute to fertility limitations with respect to oil palm growth through low $\mathrm{Ca}$ and $\mathrm{Mg}$ availability. The relationship between BS and soil pH indicates that BS increases with an increase in soil $\mathrm{pH}$, a classical relationship observed in soils. Base saturation 
Table 6. Pearson's correlation coefficients between different soil properties.

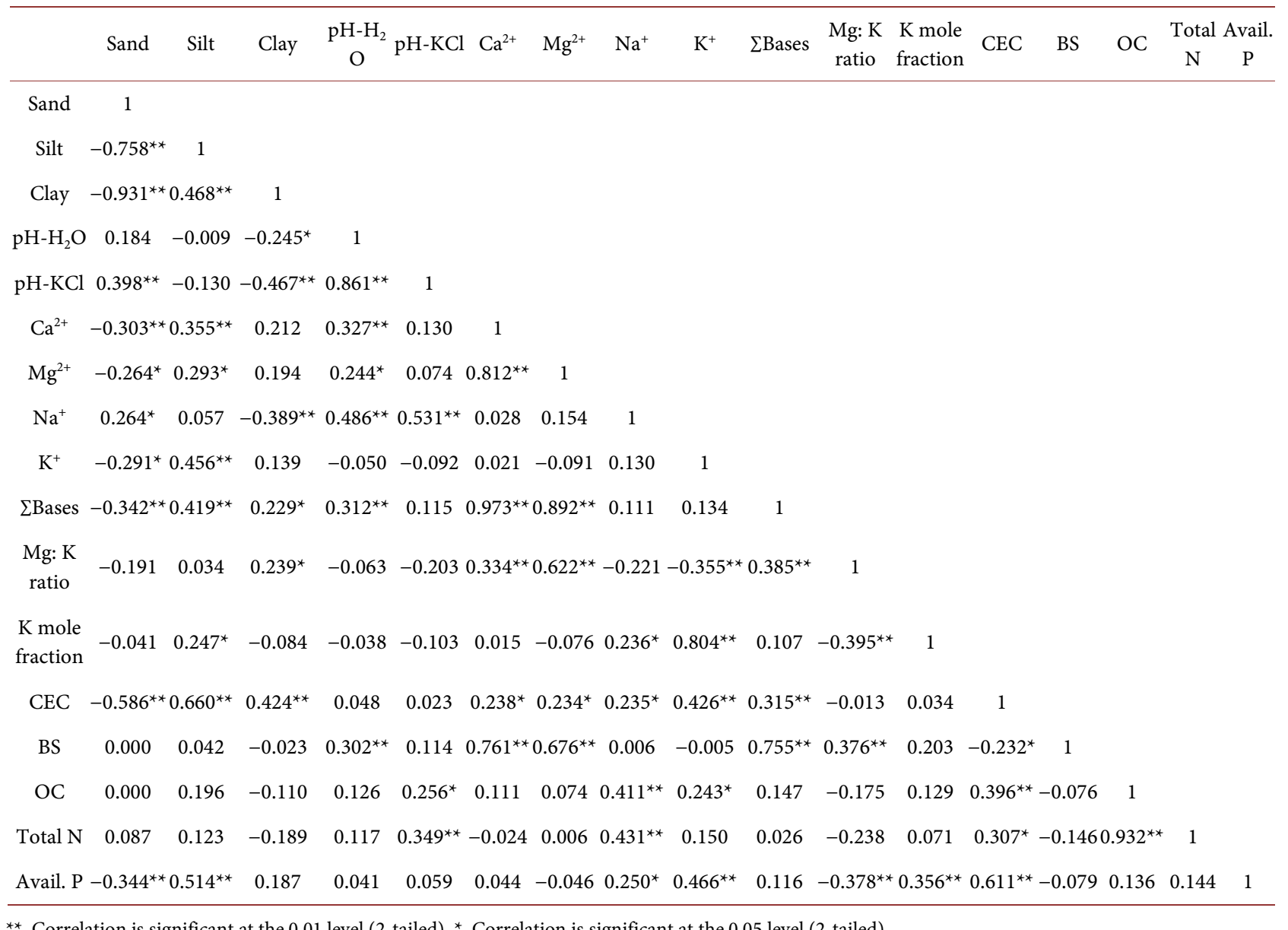

${ }^{*}$. Correlation is significant at the 0.01 level (2-tailed). ${ }^{*}$. Correlation is significant at the 0.05 level (2-tailed).

percent alongside soil $\mathrm{pH}$ are soil fertility attributes that are of considerable practical importance in relation to liming, nutrient conservation and plant growth. Soils with low BS percent have limitations in basic nutrient cations such as $\mathrm{Mg}^{2+}, \mathrm{Ca}^{2+}$ and on the $\mathrm{Mg}: \mathrm{K}$ ratio.

\subsection{Soil Organic Carbon and Cation Exchange Capacity}

Soil organic carbon ranged from low $(0.8 \%-1.2 \%)$ to high $(1.5 \%-2.0 \%)$ in most of the soils. However, most of the surface horizons had high to very high organic carbon contents. The highest organic carbon contents were observed in Debundscha, Bakingili and Bota, where the parent materials are of volcanic origin, notably pyroclastic materials. These pyroclastic materials contain minerals such as allophane which form stable allophane-humus complexes [21]. On the other hand, very low to moderate $\mathrm{OC}$ contents were observed in soils developed from sedimentary parent materials with relatively higher amounts of sand contents such as in Boa, Mafanja, Kumbe and Meme. It has been reported that most sedimentary soils in the coastal lowlands of southwest Cameroon are dominated by quartz, feldspar and kaolinite in the silt fraction, while the clay fraction is dominated by quartz, smectite and kaolinite [8]. In general, quartz, feldspars and 
kaolinite have very low specific surface areas and so have a lower capacity of binding to organic carbon. Thus, parent material appears to be one of the main factors conditioning the variability of soil organic carbon in the area. Parent material, among other factors, has been reported to be a key driver controlling soil organic carbon storage [22].

Cation exchange capacity (CEC) correlated positively with silt and clay contents but the correlation with sand was negative and significant $(\mathrm{p}<0.01)$. This observation supports the fact that fine-texture soils (with higher specific surfaces) have the capacity of retaining more nutritive elements. Soil organic carbon showed a significant and positive correlation with $\mathrm{pH}-\mathrm{KCl}$, exchangeable $\mathrm{Na}^{+}$, exchangeable $\mathrm{K}^{+}$and CEC. The correlation between OC and CEC indicates that as the net negative charge $\left(\mathrm{pH}-\mathrm{KCl}<\mathrm{pH}-\mathrm{H}_{2} \mathrm{O}\right)$ of the soil increases, the capacity of the soil to bind to OC also increases [23]. The net negative charge of the soils promotes the retention of cations to the soil complex. There was a positive and significant correlation between CEC and exchangeable bases $\left(\mathrm{Na}^{+}, \mathrm{K}^{+}, \mathrm{Ca}^{2+}\right.$ and $\mathrm{Mg}^{2+}$ ). High CEC values (22- $37 \mathrm{meq} / 100 \mathrm{~g}$ ) were observed in soils of Mondoni and Debundscha and this is likely due to the higher organic carbon contents found in these soils. As concerns the CEC status of the soils, the different sites were grouped as follows: very high CEC (Mondoni, Debundscha), high to very high CEC (Essoasso and Mbonge), moderate to high CEC (Dieka, Bota), low to moderate CEC (Illoani, Bakingili, Likomba, Boa and Kumbe), low CEC (Mafanja) and very low CEC (Meme). The low CEC or low nutrient holding capacity of the soils is probably one of the contributing factors to very low values of nutrients such as $\mathrm{K}$ and $\mathrm{Mg}$ in the soil complex. Low CEC values seem to be a common phenomenon in coastal plain soils in sub-Saharan Africa, as have also been reported in coastal plain soils of Nigeria [24] and Tanzania [25].

\subsection{Exchangeable $\mathrm{K}^{+}$and $\mathrm{Mg}^{2+}$, $\mathrm{Mg}$ : $\mathrm{K}$ Ratio and $\mathrm{K}$ Mole Fraction}

Exchangeable $\mathrm{Mg}^{2+}$ was generally higher than $\mathrm{K}^{+}$in all the soils, with $\mathrm{Mg}$ : $\mathrm{K}$ ratios ranging from 0.1 to 45 . When the $\mathrm{Mg}$ : $\mathrm{K}$ ratio is greater than $2, \mathrm{Mg}$ status is good and deficiency is not possible [26]. Based on this, almost all sites have adequate Mg levels except for Mafanja, Kumbe, Meme and Bota, where some samples have $\mathrm{Mg}$ : $\mathrm{K}$ ratios less than 2 . The very high values of $\mathrm{Mg}$ : $\mathrm{K}$ indicate that $\mathrm{Mg}$ could influence the uptake of $\mathrm{K}$ by plants through nutrient antagonism. Compared to $\mathrm{K}^{+}$that was generally low in most of the soils, $\mathrm{Mg}^{2+}$ mostly had values ranging from high to very high. Besides the low levels of exchangeable $\mathrm{K}^{+}$, it was also observed that the $\mathrm{K}$ mole fraction was very low, ranging between 0.003 and 0.189 . The $\mathrm{K}$ mole fraction has been reported as a better index of $\mathrm{K}$ supply than exchangeable $\mathrm{K}$. The $\mathrm{K}$ mole fraction of a soil indicates if that soil will respond to $\mathrm{K}$ fertilization and soils with a $\mathrm{K}$ mole fraction $>0.015$ are unlikely to respond to $\mathrm{K}$ fertilization; soils with a mole fraction between 0.010 and 0.015 show a small to medium response; while soils with a mole fraction below 0.010 show a considerable response to $\mathrm{K}$ fertilization [19]. Based on this stratification and on the values of $\mathrm{K}$ mole fraction obtained in this study, it appears that 
soils of Bota, Likomba, Mafanja and Kumbe have high K supply and will weakly respond to $\mathrm{K}$ fertilization; soils of Essoasso have low $\mathrm{K}$ supply and will respond moderately to $\mathrm{K}$ fertilization meanwhile all the other sites have low to high $\mathrm{K}$ supplies, thereby necessitating appropriate $\mathrm{K}$ fertilization. The significant positive correlation observed between $\mathrm{K}$ mole fraction and silt content indicates that silt could be the main reservoir for the supply of $K$, compared to the sand and clay fractions that showed a significant negative correlation with $\mathrm{K}$ mole fraction. Additionally, exchangeable $\mathrm{K}^{+}$showed a significant positive correlation with silt content; meanwhile the correlation was negative with sand content. Exchangeable $\mathrm{K}^{+}$did not show any significant correlation with clay content. These results are similar to those of previous studies that reported a significant and positive correlation between $\mathrm{K}$ mole fraction and percent silt + fine sand, and a negative correlation between $\mathrm{K}$ mole fraction and clay content [19]. Contrary to these observations, other studies have reported that the clay contents of six soils developed from talc in the southern Guinea savannah zone of Nigeria had the highest exchangeable $\mathrm{K}$ contents in the clay fraction, followed by the silt fraction [27].

\subsection{Total Nitrogen and Available Phosphorus Status}

Total $\mathrm{N}$ status in most of the sites ranged from high to very high. In general, total $\mathrm{N}$ content was very high in surface horizons and reduced with soil depth, a trend similar to that of OC. The highest $\mathrm{N}$ contents were found in the surface horizons of Debundscha ( $>10 \%)$, Bakingili $(>6 \%)$, Kumbe and Bota $(>3 \%)$, while the lowest was found in Meme (0.8\%). The high $\mathrm{N}$ contents in Debundscha and Bakingili are probably due to the influence of the OC-rich pyroclastic materials in these sites. Total $\mathrm{N}$ was strongly correlated with $\mathrm{OC}(\mathrm{p}<0.01, \mathrm{r}=0.932)$ (Table 6). The highly significant and positive correlation between total $\mathrm{N}$ and OC, especially in surface horizons, is explained by the classical well-known relationship existing between total $\mathrm{N}$ and soil organic matter, given that most of soil $\mathrm{N}$ is derived from the mineralization of soil organic matter. Based on the high $\mathrm{N}$ status of these soils, $\mathrm{N}$ nutrition in the oil palm may not be a major concern. This is because with high $\mathrm{N}$ status, there is very weak response to fertilizer inputs and $\mathrm{N}$ application should thus be reduced in order to avoid $\mathrm{N}$ : K imbalance. The very high $\mathrm{N}$ contents may also be a cause for concern with regards to its effects on oil palm yield. Generally, excess $\mathrm{N}$ in relation to other elements such as $\mathrm{K}$ can reduce yields by rendering the palms more susceptible to diseases and attacks from leaf-eating insects (e.g. caterpillars, bagworms) and also by depressing the oil-to-bunch ratio [28].

As concerns available $\mathrm{P}$ content, most of the soils had very low $\mathrm{P}$ status with the exception of Debundscha (moderate), Likomba (moderate to high) and Kumbe (low to moderate). Although correlation analysis did not reveal any significant relationship between available $\mathrm{P}$ and soil $\mathrm{pH}$ (Table 6), it was generally observed that the four sites with low to high $\mathrm{P}$ status had higher $\mathrm{pH}$ values, especially in subsurface horizons. There was however a significant $(\mathrm{p}<0.01)$ and 
positive correlation between available $\mathrm{P}$ and $\mathrm{Na}^{+}, \mathrm{K}^{+}, \mathrm{CEC}$ and $\mathrm{K}$ mole fraction. The positive and significant $(\mathrm{p}<0.05)$ correlation between available $\mathrm{P}$ and basic cations $\left(\mathrm{Na}^{+}\right.$and $\left.\mathrm{K}^{+}\right)$indicates that $\mathrm{P}$ content in soil increases with increase in soil $\mathrm{pH}$. In sites with very low $\mathrm{P}$ status, deficiency symptoms may be observed in the plant (e.g. reduction in frond length, trunk diameter and bunch size). On $\mathrm{P}$-deficient soils, response to applied $\mathrm{N}$ and $\mathrm{K}$ are often high. Therefore, $\mathrm{P}$ fertilizer rates have to be increased to the corrective levels. Available P correlated negatively and positively with sand and silt contents respectively. The relationship between available $\mathrm{P}$ and sand content indicates that as the relative percentage of sand increases in the soil, $\mathrm{P}$ losses become more pronounced, for example through mechanisms of leaching, given that the soil becomes more susceptible to high rates of water infiltration [29]. Additionally, sandy soils have very low specific surfaces for retaining the phosphate ions.

\subsection{Potential and Actual Soil Fertility and Major Limitations to Oil Palm Growth}

Results of land suitability evaluation are shown in Table 7. The potential soil fertility (based on CEC, OC, BS and soil $\mathrm{pH}-\mathrm{H}_{2} \mathrm{O}$ ) shows that almost all the soils have limitations in at least one of the aforementioned properties. The proportion of soils with different levels of chemical fertility limitations with respect to different parent materials is shown in Table 8. The table indicates that soils developed on sedimentary parent materials have more limitations than those developed on volcanic parent materials. In general, volcanic parent materials have more fertile young volcanic ash (mineral) soils which are richer in plant nutrients, compared to those found on old coastal sediments, this as a result of the presence of more weatherable primary minerals present in young volcanic soils. These soil minerals influence soil fertility status by controlling the release and supply of nutrients and by influencing soil physical properties. Soil physical properties (such as texture, structure, drainage, porosity, effective soil depth) and chemical properties (such as soil $\mathrm{pH}, \mathrm{C}$ content, $\mathrm{N}$ content, $\mathrm{P}$ content, CEC, base saturation and exchangeable bases) as influenced by parent material, have a direct influence on soil fertility and plantation management [18]. It has been reported that oil palm growth and yield greatly depends on the potential of the soil parent material to supply nutrients [30].

Base saturation was a major soil fertility constraint in Illoani, Debundscha, Bakingili, Boa and Mafanja. CEC was a major limitation in Illoani, Mafanja, Kumbe and Meme. Soil $\mathrm{pH}-\mathrm{H}_{2} \mathrm{O}$ limitations were observed in Illoani, Kumbe and Meme. In general, most of the soils do not have limitations in soil OC, except for Illoani, Mafanja and Meme, where there is slight limitation. As concerns the actual or current soil fertility (which takes into consideration the $\mathrm{K}$ mole fraction and $\mathrm{Mg}: \mathrm{K}$ ratio), $\mathrm{Mg}: \mathrm{K}$ ratio was slightly limiting in Mafanja and Meme, while the limitation was moderate in Kumbe and Bota. Potassium mole fraction was the most limiting soil fertility property in all the soils with a rating of 40/100 (S3) in all the sites. Soil K mole fraction was also observed as the main soil 
Table 7. Suitability class scores of representative soil profiles in the various sites.

\begin{tabular}{|c|c|c|c|c|c|c|c|c|c|c|c|c|c|}
\hline \multirow{2}{*}{$\begin{array}{l}\text { Land } \\
\text { requirements/ } \\
\text { characteristics }\end{array}$} & \multicolumn{13}{|c|}{ Site } \\
\hline & Mondoni & i Essoasso & Illoani & Debundscha & a Bakingili & Likomba & Boa & Dieka & Mafanja & Kumbe & Meme & Mbonge & Bota \\
\hline \multicolumn{14}{|l|}{ Climate (c) } \\
\hline $\begin{array}{c}\text { Annual } \\
\text { rainfall }(\mathrm{mm})\end{array}$ & S1 (100) & S1 (100) & S1 (100) & S1 (100) & S1 (100) & S1 (100) & S1 (100) & S1 (100) & S1 (100) & S1 (100) & S1 (100) & S1 (100) & S1 (100) \\
\hline $\begin{array}{l}\text { Length of } \\
\text { dry season } \\
\text { (months) }\end{array}$ & S3 (60) & S3 (60) & S3 (60) & S2 (85) & S2 (85) & S3 (60) & S3 (60) & S3 (60) & S3 (60) & S3 (60) & S3 (60) & S3 (60) & S3 (60) \\
\hline $\begin{array}{l}\text { Mean annual } \\
\text { max. temp. } \\
\left({ }^{\circ} \mathrm{C}\right)\end{array}$ & S3 (59.3) & S3 (57.3) & S3 (59.3) & S3 (58.0) & S3 (54.0) & S3 (57.3) & S3 (59.3) & S1 (100) & S1 (100) & S2 (60.1) & S3 (56.7) & S3 (47.3) & S1 (100) \\
\hline $\begin{array}{l}\text { Mean annual } \\
\text { min. temp. } \\
\left({ }^{\circ} \mathrm{C}\right)\end{array}$ & S1 (100) & S1 (100) & S1 (100) & S1 (100) & S1 (100) & S1 (100) & S1 (100) & S1 (100) & S1 (100) & S1 (100) & S1 (100) & S1 (100) & S1 (100) \\
\hline $\begin{array}{c}\text { Mean annual } \\
\text { temp. }\left({ }^{\circ} \mathrm{C}\right)\end{array}$ & S1 (100) & S1 (100) & S1 (100) & S1 (100) & S1 (100) & S1 (100) & S1 (100) & S1 (100) & S1 (100) & S1 (100) & S1 (100) & S2 (77.4) & S1 (100) \\
\hline $\begin{array}{c}\text { Relative } \\
\text { humidity (\%) }\end{array}$ & S1 (100) & S1 (100) & S1 (100) & S1 (100) & S1 (100) & S1 (100) & S1 (100) & S1 (100) & S1 (100) & S1 (100) & S1 (100) & S1 (100) & S1 (100) \\
\hline \multicolumn{14}{|l|}{$\begin{array}{c}\text { Topography } \\
(t)\end{array}$} \\
\hline Slope (\%) & S1 (95) & S1 (95) & S1 (95) & S1 (90) & S1 (90) & S1 (95) & S1 (95) & S1 (95) & S1 (95) & S1 (95) & S1 (95) & S1 (95) & S1 (90) \\
\hline \multicolumn{14}{|l|}{ Wetness (w) } \\
\hline Drainage class & S3 (60) & S1 (85) & S3 (60) & S2 (85) & S2 (85) & S1 (85) & S3 (60) & S2 (60) & S2 (85) & S1 (85) & S1 (85) & S2 (85) & S2 (85) \\
\hline Flooding & S3 (60) & S3 (60) & N1 (40) & S2 (85) & S2 (85) & S3 (60) & N1 (40) & S3 (60) & S2 (85) & S3 (60) & S3 (60) & S2 (85) & S1 (100) \\
\hline \multicolumn{14}{|l|}{$\begin{array}{l}\text { Soil physical } \\
\text { properties (s) }\end{array}$} \\
\hline $\begin{array}{l}\text { Texture/ } \\
\text { structure }\end{array}$ & S3 (60) & S1 (85) & S3 (60) & S3 (60) & - & S1 (85) & S1 (85) & S1 (85) & S3 (60) & S1 (85) & S1 (85) & S3 (60) & S3 (60) \\
\hline $\begin{array}{l}\text { Coarse } \\
\text { fragments }\end{array}$ & S1 (100) & S1 (100) & S1 (100) & - & - & S1 (100) & S1 (100) & S1 (100) & S1 (100) & S1 (100) & S1 (100) & S1 (100) & S2 (85) \\
\hline Soil depth & S1 (100) & S1 (100) & S1 (100) & S2 (79) & S1 (100) & S1 (100) & S1 (100) & S1 (100) & S1 (100) & S1 (100) & S1 (100) & S1 (100) & S1 (100) \\
\hline \multicolumn{14}{|l|}{$\begin{array}{l}\text { Soil fertility } \\
\text { conditions (f) }\end{array}$} \\
\hline $\begin{array}{c}\text { CEC } \\
(\mathrm{meq} / 100 \mathrm{~g})\end{array}$ & S1 (100) & S1 (100) & S2 (62) & S1 (100) & S2 (72) & S2 (72) & S2 (72) & S2 (72) & S2 (60) & S2 (60) & S2 (60) & S1 (100) & S1 (100) \\
\hline $\begin{array}{c}\mathrm{pH}-\mathrm{H}_{2} \mathrm{O} \\
\text { topsoil }\end{array}$ & S1 (85) & S1 (85) & S3 (48) & S1 (90) & S1 (85) & S1 (98) & S1 (85) & S1 (99) & S1 (97.5) & S2 (66) & S2 (69) & S1 (100) & S1 (100) \\
\hline $\begin{array}{c}\text { Base } \\
\text { saturation (\%) }\end{array}$ & S1 (100) & S2 (81) & S3 (50) & S3 (60) & S3 (40) & S1 (100) & S2 (70) & S1 (90) & S2 (70) & S1 (100) & S1 (84) & S1 (90) & S1 (100) \\
\hline $\begin{array}{c}\text { Organic } \\
\text { carbon (\%) } \\
0-15 \mathrm{~cm}\end{array}$ & S1 (100) & S1 (100) & S2 (74) & S1 (100) & S1 (100) & S1 (100) & S1 (100) & S1 (100) & S2 (80) & S1 (100) & S2 (72) & S1 (100) & S1 (100) \\
\hline Mg: $\mathrm{K}$ ratio & S1 (100) & S1 (100) & S1 (100) & S1 (100) & S1 (100) & S1 (100) & S1 (100) & S1 (100) & S3 (60) & N1 (40) & S3 (60) & S1 (100) & S3 (60) \\
\hline
\end{tabular}




\begin{tabular}{|c|c|c|c|c|c|c|c|c|c|c|c|c|c|}
\hline \multicolumn{14}{|l|}{ Continued } \\
\hline $\begin{array}{l}\mathrm{K} \text { mole } \\
\text { fraction }\end{array}$ & S3 (40) & S3 (40) & S3 (40) & S3 (40) & S3 (40) & S3 (40) & S3 (40) & S3 (40) & S3 (40) & S3 (40) & S3 (40) & S3 (40) & S3 (40) \\
\hline \multicolumn{14}{|c|}{$\begin{array}{l}\text { Salinity and } \\
\text { alkalinity (n) }\end{array}$} \\
\hline $\begin{array}{c}\mathrm{EC}(\mathrm{dS} / \mathrm{m}) \\
(50 \mathrm{~cm})\end{array}$ & - & - & - & - & - & - & - & - & - & - & - & - & - \\
\hline \multicolumn{14}{|l|}{$\begin{array}{l}\text { Aggregate } \\
\text { suitability }\end{array}$} \\
\hline Potential & $45(\mathrm{~S} 3)$ & $62.5(\mathrm{~S} 2)$ & $23(\mathrm{~N})$ & $50(\mathrm{~S} 2)$ & $46(\mathrm{~S} 3)$ & $38(\mathrm{~S} 3)$ & $32(\mathrm{~S} 3)$ & 39 (S3) & $32(\mathrm{~S} 3)$ & $32(\mathrm{~S} 3)$ & $31(\mathrm{~S} 3)$ & $48(\mathrm{~S} 3)$ & $52(\mathrm{~S} 2)$ \\
\hline Actual & $18(\mathrm{~N})$ & 25 (S3) & $15(\mathrm{~N})$ & $20(\mathrm{~N})$ & $26(\mathrm{~S} 3)$ & $21(\mathrm{~N})$ & $18(\mathrm{~N})$ & $22(\mathrm{~N})$ & $22(\mathrm{~N})$ & $22(\mathrm{~N})$ & $21(\mathrm{~N})$ & $19(\mathrm{~N})$ & $21(\mathrm{~N})$ \\
\hline
\end{tabular}

Table 8. Percentage of soils with chemical fertility limitations for volcanic and sedimentary parent materials.

\begin{tabular}{|c|c|c|c|c|c|c|c|c|c|c|c|c|c|c|c|}
\hline \multirow{2}{*}{$\begin{array}{l}\text { Fertility } \\
\text { attributes }\end{array}$} & \multicolumn{9}{|c|}{ Sites with sedimentary parent materials } & \multirow{2}{*}{$\begin{array}{c}\% \\
\text { Lim. }\end{array}$} & \multicolumn{4}{|c|}{ Sites with volcanic parent materials } & \multirow{2}{*}{$\begin{array}{c}\% \\
\text { Lim. }\end{array}$} \\
\hline & Mondoni & Essoasso & Kumbe & Illoani & Dieka & Mafanja & Likomba & Boa & Meme & & Bakingili & Debundscha & Mbonge & Bota & \\
\hline $\mathrm{pH}$ & - & - & + & + & - & - & - & - & + & 33.3 & - & - & - & - & 0.0 \\
\hline OC $(\%)$ & - & - & - & + & - & + & - & - & + & 33.3 & - & - & - & - & 0.0 \\
\hline $\begin{array}{c}\text { CEC } \\
(\mathrm{meq} / 100 \mathrm{~g})\end{array}$ & - & - & + & + & + & + & + & + & + & 77.8 & + & - & - & - & 25.0 \\
\hline BS (\%) & - & + & - & + & - & + & - & - & - & 33.3 & + & + & - & - & 50.0 \\
\hline Mg: K ratio & - & - & + & - & - & + & - & - & + & 33.3 & - & - & - & + & 25.0 \\
\hline $\begin{array}{l}\mathrm{K} \text { mole } \\
\text { fraction }\end{array}$ & + & + & + & + & + & + & + & + & + & 100.0 & + & + & + & + & 100.0 \\
\hline
\end{tabular}

Notes: +; limiting, -; non-limiting, \% Lim.; percent limitation.

fertility constraint in soils of the Nigerian Institute for Oil Palm Research [17]. The low values of exchangeable $\mathrm{K}$ in these soils are likely due to the low CEC (low nutrient holding capacity) and the high amounts of rainfall which promote leaching of cations and other soil nutrients. Therefore, appropriate soil fertility management with respect to $\mathrm{K}$ fertilization is required in order to render the soils suitable for improving yields. Potassium is the largest single nutritional factor that determines oil palm yield [31]. This is because $\mathrm{K}$ plays a major role in proper functioning of the stomata and so prevents drought conditions, promotes the transportation of assimilates from photosynthesis, helps in enzyme activation and oil synthesis, affects bunch size and number, and makes the plant disease-resistant. A very strong correlation between $\mathrm{K}$ mole fraction and oil palm yield in soils of southern Nigeria has been reported [17].

In general, climate is not a major limitation to oil palm growth in southwest Cameroon, except for some few locations where mean annual maximum temperature is only slightly limiting. As concerns soil moisture conditions, poor drainage is a major concern in Mondoni, Illoani, Boa and Dieka. Flooding is a major constraint in Illoani and Boa, and so, proper management techniques are required for making the soils suitable for oil palm growth. Water management is a crucial aspect of oil palm cultivation since a deficit or an excess of water will 
lead to stresses in the oil palm thereby leading to poor yields. Studies have shown that impeded drainage as caused by high water tables can significantly reduce oil palm yields by affecting net photosynthesis, and stomata conductance and transpiration [32]. Flat and flooded areas with high clay contents like those in the present study could be managed by establishing drainage systems in order to remove excess water and promote oil palm root proliferation in the deeper soil layers. Details on water management options in flooded oil palm plantations have been reported [33]. Drainage systems such as the creation of drainage canals, dykes, and retention basins are very costly to establish and maintain, but are however necessary for oil palm intensification instead of promoting deforestation for the expansion of oil palm plantations. Soil physical characteristics do not pose major limitations except for the sites with very high clay contents. Oil palm generally grows well in soils with a sandy clay loam texture where the water holding capacity is good. With a clayey texture, water stagnation becomes a major problem because the optimum depth of water table for oil palm growth is between $50-75 \mathrm{~cm}[33]$.

\section{Conclusion}

This study reveals that most of the soils supporting oil palm plantations in coastal lowlands of southwest Cameroon are marginally suitable, owing to soil fertility constraints (such as low CEC, low BS and very low K contents) and limitations caused by soil physical properties such as texture and drainage. Based on the parametric method of land evaluation used in this study, it has been possible to identify specific factors in soils derived from dissimilar parent materials that need to be adjusted in order to render the soils suitable, which might certainly improve oil palm yields. Based on these limiting factors, the two main management concerns that need to be addressed in order to increase oil palm yield are: the establishment of drainage schemes for water management, and the application of chemical fertilizers, especially $\mathrm{K}$ fertilizers, in the right amounts, while taking into account $\mathrm{N}, \mathrm{P}$ and $\mathrm{Mg}$ status. A precondition for appropriate fertilizer application should be site-specific soil fertility investigations, owing to the diversity of these soils, especially soil and leaf sampling and testing analysis. There is also an urgent need to establish a fertilizer recommendation system for sustainable intensification of oil palm production in the coastal plains of Southwest Cameroon.

\section{Conflicts of Interest}

The authors declare no conflicts of interest regarding the publication of this paper.

\section{References}

[1] Fairhurst, T. and Mutert, E. (1999) Introduction to Oil Palm Production. Better Crops International, 13, 3-6.

[2] UNEP (2011) Oil Palm Plantations: Threats and Opportunities for Tropical Ecosys- 
tems. UNEP Global Environmental Alert Service (GEAS), 8.

[3] Obi, J.C. and Udoh, B.T. (2012) Nutrient Budget for Optimal Oil Palm (Elaeis guineensis Jacq) Yield on Coastal Plain Sands Soils of Akwa Ibom State Nigeria. Open Journal of Soil Science, 2, 289-298. https://doi.org/10.4236/ojss.2012.23035

[4] Mutert, E. (1999) Suitability of Soils for Oil Palm in South East Asia. Better Crops International, 13, 36-38.

[5] FAO (2014) FAOSTAT Gateway. http://www.fao.org/faostat/en/\#home

[6] Pingpoh, D.P. and Senahoun, J. (2008) Extent and Impact of Vegetable Oils Import Surges in Cameroon. 12 th EAAE Congress "People, Food and Environments: Global Trends and European Strategies", Ghent, 26-29 August 2008, 1-11.

[7] Hasselo, H.N. (1961) The Soils of the Lower Eastern Slopes of the Cameroon Mountain and Their Suitability for Various Perennial Crops. Veenman en Zonen NV, Wageningen, 67 p. https://doi.org/10.1097/00010694-196205000-00026

[8] Kips, P., Van Ranst, E., Krook, L. and Zambo, J. (1991) Morphology, Mineralogy and Exchange Properties as Related to Geomorphic Position of Soils in Tiko Plain, Coastal West Cameroon. Catena, 18, 213-231. https://doi.org/10.1016/0341-8162(91)90018-S

[9] Wyrley-Birch, E.A., Anderson, I.P., Cox, W.J.R., Errington, M. and Walker, S.H. (1982) Land Suitability and Feasibility Study for Oil Palm and Rubber Plantations in South-West Cameroon. Volume 1 Main Report. Land Resources Development Centre, Overseas Development Administration, Tolworth Tower, Surbiton, 123 p.

[10] Pirker, J. and Mosnier, A. (2015) Global Oil Palm Suitability Assessment. IIASA Interim Report, 27.

[11] Pirker, J. (2015) Mapping Oil Palm Suitability Protocol. Technical Annex 1. Oil Palm Suitability Map for South West Cameroon. IEL International, 23.

[12] Bouyoucos, G.J. (1962) Hydrometer Method Improved for Making Particle Size Analysis of Soil. Agronomy Journal, 54, 464-465. https://doi.org/10.2134/agronj1962.00021962005400050028x

[13] Pauwels, J.M., Van Ranst, E., Verloo, M. and Mvondo Ze, A. (1992) Manuel de laboratoire de pédologie. Méthodes d'analyses des sols et des plantes, équipement, gestion de stocks de verrerie et de produits chimiques. Publications Agricoles 28, Bruxelles.

[14] Sys, C., Van Ranst, E. and Debaveye, J. (1991) Land Evaluation. Part I: Principles in Land Evaluation and Crop Production Calculations. Agric. Pub. No. 7, General Administration for Development Cooperation, Brussels.

[15] Sys, C., Van Ranst, E. and Debaveye, J. (1991) Land Evaluation. Part II: Methods in Land Evaluation. Agric. Pub. No. 7, General Administration for Development Cooperation, Brussels.

[16] Sys, C., Van Ranst, E. and Debaveye, J. (1993) Land Evaluation. Part III: Crop Requirements. Agric. Pub. No. 7, General Administration for Development Cooperation, Brussels.

[17] Ogunkunle, O.A. (1993) Soil in Land Suitability Evaluation: An Example with Oil Palm in Nigeria. Soil Use Manage, 9, 35-40. https://doi.org/10.1111/j.1475-2743.1993.tb00925.x

[18] Paramananthan, S. (2013) Soil Properties and Their Influence on Oil Palm Management and Yield. In: Webb, M.J., Nelson, P.N., Bessou, C., Caliman, J.P. and Sutarta, E.S., Eds., Sustainable Management of Soil in Oil Palm Plantings, Australian Centre for International Agricultural Research, Canberra, 70. 
[19] Unamba-Oparah, I. (1985) The Potassium Status of the Sandy Soils of Northern Imo State, Nigeria. Soil Science, 139, 437-448. https://doi.org/10.1097/00010694-198505000-00009

[20] Nelson, P.N., Rhebergen, T., Berthelsen, S., Michael, J.W., Banabas, M., Oberthiir, T., Donough, C.R., Rahmadsyah, Indrasuara, K. and Lubis, A. (2011) Soil Acidification under Oil Palm: Rates and Effects on Yield. Better Crops with Plant Food, 95, 22-25.

[21] Yerima, B.P.K. and Van Ranst, E. (2005) Introduction to Soil Science: Soils of the Tropics. Trafford Publishing, Victoria.

[22] Gray, J.M., Bishop, T.F. and Wilson, B.R. (2015) Factors Controlling Soil Organic Carbon Stocks with Depth in Eastern Australia. Soil Science Society of America Journal, 79, 1741-1751. https://doi.org/10.2136/sssaj2015.06.0224

[23] Kaiser, K. and Guggenberger, G. (2003) Mineral Surfaces and Soil Organic Matter. European Journal of Soil Science, 54, 219-236. https://doi.org/10.1046/j.1365-2389.2003.00544.x

[24] Ibia, T.O. and Udo, E.J. (1993) Phosphorus Forms and Fixation Capacity of Representative Soils in Akwa Ibom State of Nigeria. Geoderma, 58, 95-106. https://doi.org/10.1016/0016-7061(93)90087-2

[25] Hartemink, A.E. and Bridges, E.M. (1995) The Influence of Parent Material on Soil Fertility Degradation in the Coastal Plain of Tanzania. Land Degradation and Rehabilitation, 6, 215-221. https://doi.org/10.1002/ldr.3400060403

[26] Tinker, P.B. and Smilde, K.W. (1963) Cation Relationships and Magnesium Deficiency in the Oil Palm. Journal of the West African Institute for Oil Palm Research, 4, 82-100.

[27] Ajiboye, G.A. and Ogunwale, J.A. (2008) Potassium Distribution in the Sand, Silt and Clay Separates of Soils Developed over Talc at Ejiba, Kogi State, Nigeria. World Journal of Agricultural Sciences, 4, 709-716.

[28] Von Uexkull, H.R. and Fairhurst, T.H. (1992) Oil Palm. International Potash Institute, Singapore.

[29] Chardon, W.J. and Schoumans, O.F. (2007) Soil Texture Effects on the Transport of Phosphorus from Agricultural Land in River Deltas of Northern Belgium, the Netherlands and North-West Germany. Soil Use and Management, 23, 16-24. https://doi.org/10.1111/j.1475-2743.2007.00108.x

[30] Woittiez, L.S., van Wijk, M.T., Slingerland, M., van Noordwijk, M. and Giller, K.E. (2017) Yield Gaps in Oil Palm: A Quantitative Review of Contributing Factors. European Journal of Agronomy, 83, 57-77. https://doi.org/10.1016/j.eja.2016.11.002

[31] Rankine, I. and Fairhurst, T.H. (1999) Management of Phosphorus, Potassium and Magnesium in Mature Oil Palm. Better Crops International, 13, 10-15.

[32] Henson, I.E., Harun, M.H. and Chang, K.C. (2008) Some Observations on the Effects of High Water Tables and Flooding on Oil Palm, and a Preliminary Model of Oil Palm Water Balance and Use in the Presence of a High Water Table. Oil Palm Bulletin, 56, 14-22.

[33] Comte, I., Colin, F., Whalen, J.K., Grünberger, O. and Caliman, J.P. (2012) Agricultural Practices in Oil Palm Plantations and Their Impact on Hydrological Changes, Nutrient Fluxes and Water Quality in Indonesia: A Review. Advances in Agronomy, 116, 71-124. https://doi.org/10.1016/B978-0-12-394277-7.00003-8 